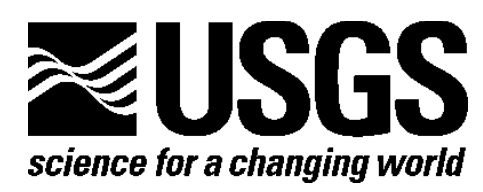

\title{
A Preliminary Deposit Model for Lithium-Cesium-Tantalum (LCT) Pegmatites
}

By Dwight Bradley and Andrew McCauley

Open-File Report 2013-1008

Version 1.1, December 2016

U.S. Department of the Interior

U.S. Geological Survey 


\section{U.S. Department of the Interior \\ SALLY JEWELL, Secretary}

\section{U.S. Geological Survey \\ Suzette M. Kimball, Director}

\section{U.S. Geological Survey, Reston, Virginia}

First release: 2013

Revised: December 2016 (ver 1.1)

For more information on the USGS—-the Federal source for science about the Earth, its natural and living resources, natural hazards, and the environment-visit http://www.usgs.gov/ or call 1-888-ASK-USGS (1-888-275-8747).

For an overview of USGS information products, including maps, imagery, and publications, visit http://store.usgs.gov/.

Any use of trade, firm, or product names is for descriptive purposes only and does not imply endorsement by the U.S. Government.

Although this information product, for the most part, is in the public domain, it also may contain copyrighted materials as noted in the text. Permission to reproduce copyrighted items must be secured from the copyright owner.

Suggested citation:

Bradley, Dwight, and McCauley, Andrew, 2013, A preliminary deposit model for lithium-cesium-tantalum (LCT) pegmatites (ver. 1.1, December 2016): U.S. Geological Survey Open-File Report 2013-1008, 7 p., https://doi.org/10.3133/ofr20131008.

ISSN 2331-1258 (online) 


\section{Contents}

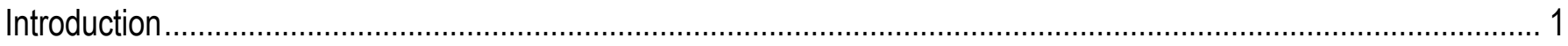

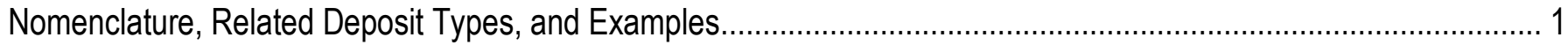

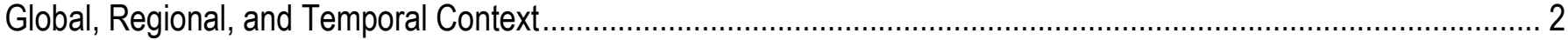

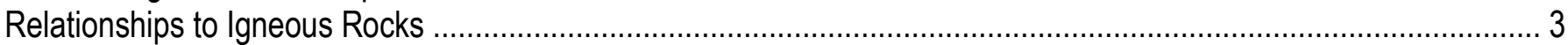

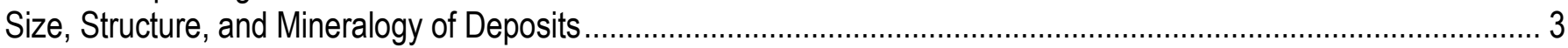

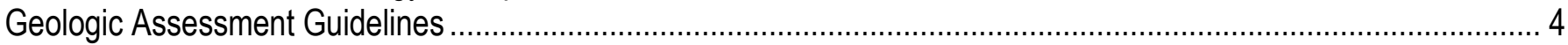

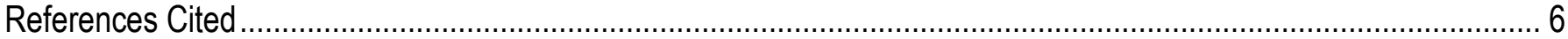

\section{Figures}

Figure 1. World map showing the locations of LCT pegmatite deposits or districts ........................................... 2

Figure 2. Deposit-scale zoning patterns in an idealized pegmatite .......................................................... 4 


\section{A Preliminary Deposit Model for Lithium-Cesium-Tantalum (LCT) Pegmatites}

By Dwight Bradley and Andrew McCauley

\section{Introduction}

This report is part of an effort by the U.S. Geological Survey (USGS) to update existing mineral deposit models and to develop new ones. We emphasize practical aspects of pegmatite geology that might directly or indirectly help in exploration for lithium-cesium-tantalum (LCT) pegmatites, or for assessing regions for pegmatite-related mineral resource potential. These deposits are an important link in the world's supply chain of rare and strategic elements, accounting for about one-third of world lithium production, most of the tantalum, and all of the cesium (U.S. Geological Survey, 2011).

\section{Nomenclature, Related Deposit Types, and Examples}

London (2008) defined pegmatite as: "an essentially igneous rock, commonly of granitic composition, that is distinguished from other igneous rocks by its extremely coarse but variable grainsize, or by an abundance of crystals with skeletal, graphic, or other strongly directional growth-habits." LCT pegmatites are a petrogenetically defined subset of granitic pegmatites that are associated with certain granites. They consist mostly of quartz, potassium feldspar, albite, and muscovite. Common accessory minerals include garnet, tourmaline, and apatite. The major lithium ore minerals are spodumene, petalite, and lepidolite; cesium mainly comes from pollucite; and tantalum mostly comes from columbite-tantalite. The tin ore, cassiterite, and the beryllium ore, beryl, also occur in LCT pegmatites, as do a number of gemstones and high-value museum specimens of rare minerals. Among the gemstones are: the beryl varieties emerald, heliodor, and aquamarine; the spodumene varieties kunzite and hiddenite; and watermelon tourmaline. LCT pegmatites are also mined for ultrapure quartz, potassium feldspar, albite, and muscovite.

A number of classification schemes have been proposed for granitic pegmatites, as recently summarized and critiqued by London (2008). For the purposes of exploration or assessment, two simple distinctions are particularly helpful. The first is between the common pegmatites, which have the simple mineralogy of granites. The second distinction is among rare-element pegmatites, which are mineralogically complex and are grouped on petrologic grounds into two families, the LCT pegmatites and the NYF pegmatites. The latter are characteristically enriched in niobium, yttrium, and fluorine and are associated with anorogenic magmatism.

Figure 1 shows selected LCT pegmatites or pegmatite districts of the world. The following tonnages are expressed as million tonnes $(\mathrm{Mt})$ of ore, at the indicated percentages of the oxides of tantalum and lithium, $\mathrm{Ta}_{2} \mathrm{O}_{5}$ and $\mathrm{Li}_{2} \mathrm{O}$. Giant deposits include Tanco in Canada (2.1 Mt at 0.215 percent $\mathrm{Ta}_{2} \mathrm{O}_{5}$ ), Greenbushes in Australia (70.4 Mt at 2.6 percent $\mathrm{Li}_{2} \mathrm{O}$ ), and Bikita in Zimbabwe (12 Mt at 1.4 percent $\mathrm{Li}_{2} \mathrm{O}$ ). The United States was once a major producer of lithium from pegmatites; among the important districts were King's Mountain, North Carolina, and the Black Hills, South Dakota. 


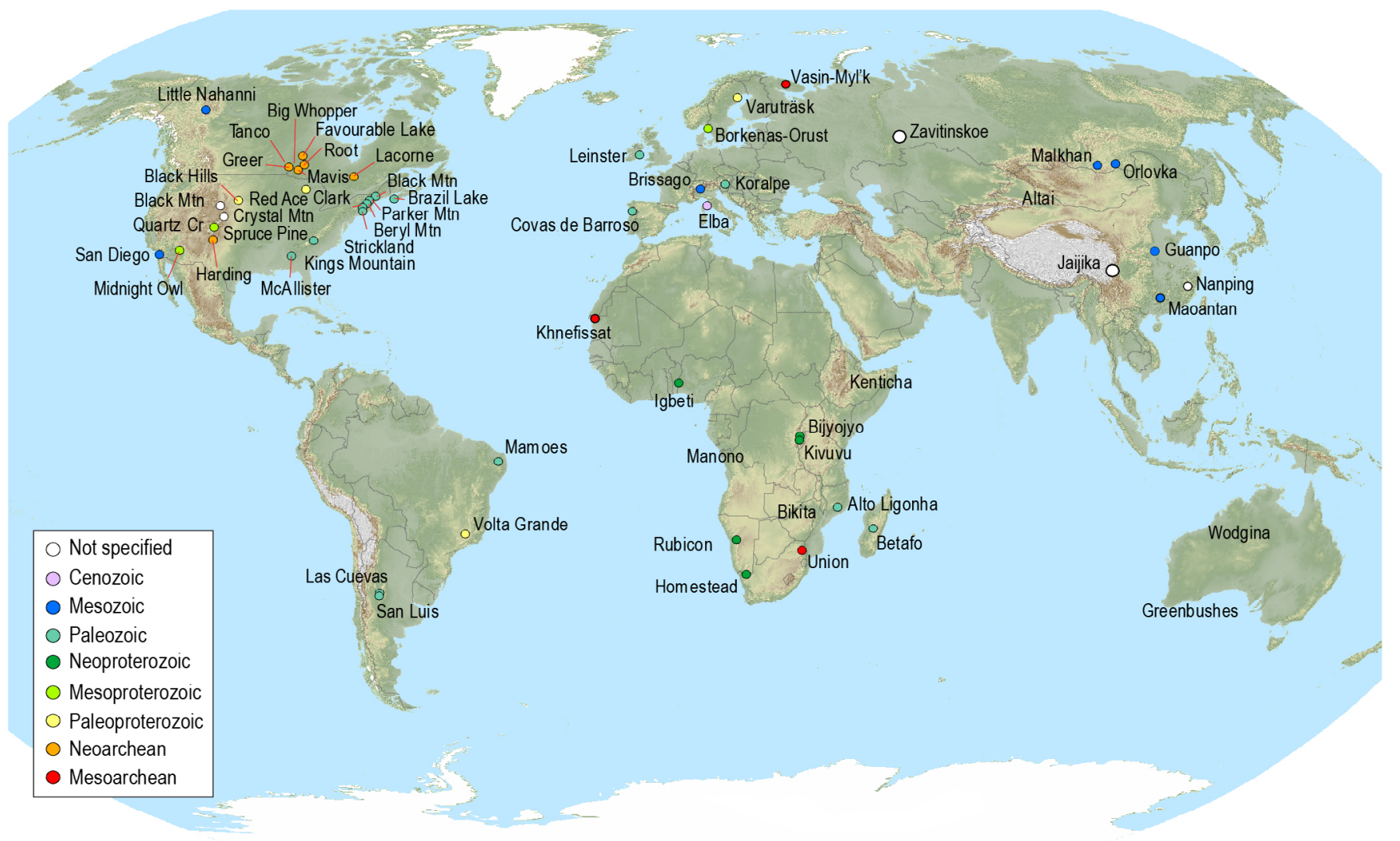

Figure 1. World map showing the locations of LCT pegmatite deposits or districts, including smaller districts in the United States. The symbols are color-coded by age. Giant deposits are represented by larger symbols.

\section{Global, Regional, and Temporal Context}

All LCT pegmatites were emplaced into orogenic hinterlands, even those now in the cores of Precambrian cratons. They are products of plate convergence. Examples are known from both convergent-margin orogens (Himalaya pegmatite, California) and collisional orogens (Mt. Mica, Maine). Contrary to the suggestion of Martin and De Vito (2005), the majority can be tied to collision rather than subduction. So far, few if any LCT pegmatites have been linked to specific plate-tectonic events such as: ordinary arc processes; overthickening of continental crust during collision or subduction; slab breakoff during or after collision; slab delamination during or after collision; and late collisional extensional collapse and consequent decompression melting. At present, only generalizations can be made. For example, based on a global survey, Ĉerný (1991) suggested that most LCT pegmatites are late syntectonic to early post-tectonic with respect to enclosing rocks.

Most LCT pegmatites intruded metasedimentary rocks, typically at low-pressure amphibolite to upper greenschist facies (Ĉerný, 1992). This metamorphic grade setting is a guideline rather than a requirement. A few LCT pegmatites are in granite (Greer Lake, Canada) (Ĉerný and others, 2005), gabbro (Pala Chief, California) (Symons and others, 2009), or other igneous rocks. Unmetamorphosed sedimentary or volcanic successions are not prospective.

The global age distribution of LCT pegmatites (Tkachev, 2011; McCauley and Bradley, 2011) is similar to the age distributions of orogenic granites and detrital zircons (Bradley, 2011). LCT pegmatite 
maxima at ca. 2650,1800,525, 350, and 100 Ma correspond to times of collisional orogeny and, except for the comparatively minor peak at $100 \mathrm{Ma}$, to times of supercontinent assembly (Bradley, 2011).

Between these pulses were long intervals of few or no LCT pegmatites. The global LCT minima overlap with supercontinent tenures at ca. 2450-2225, 1625-1000, 875-725, and 250-200 Ma (Bradley, 2011). The age distribution would appear to provide a first-order filter in the search for LCT pegmatites in frontier regions. The most significant change in LCT pegmatites through Earth's history is that, by far, the largest deposits are Archean. Thus, for whatever reason, the potential for giant deposits seems greatest in orogens of that age.

\section{Relationships to Igneous Rocks}

LCT pegmatites represent the most highly differentiated and last to crystallize components of certain granitic melts. Parental granites are typically peraluminous, S-type granites, although some Archean examples are metaluminous, I-type granites (Martin and De Vito, 2005). Genetic links between a pegmatite and its parental granite have been established through various lines of evidence. In the clearest cases, the two can be linked by physical continuity (Greer Lake, Canada) (Ĉ́erný and others, 2005). Pegmatites at Ghost Lake, Canada, show a regional zoning pattern with respect to the parental granite, with the greatest enrichment in incompatible elements in the more distal pegmatites (Breaks and Moore, 1992). Presumably because of such regional distribution, a number of pegmatites (for example, Brazil Lake, Canada) (Kontak, 2006) have only an inferred, buried plutonic parent. In this kind of LCT field, the structurally highest pegmatites are particularly promising for rare-element enrichment.

LCT pegmatites are enriched in the incompatible elements lithium, cesium, tin, rubidium, and tantalum, and are distinguished from other rare-element pegmatites by this diagnostic suite of elements. The melts from which LCT pegmatites crystallize are enriched in fluxing components including water, fluorine, phosphorus, and boron; these reduce the solidus temperature, viscosity, and density while increasing the bulk diffusivity of the melt. Pegmatites can thus form thin dikes and massive crystals despite their felsic composition and significant subliquidus undercooling. Fluid inclusion studies of various pegmatites suggest formation at $\approx 350-550{ }^{\circ} \mathrm{C}$ and relatively low pressures in the range of $3 \mathrm{~kb}$ (London, 2008).

\section{Size, Structure, and Mineralogy of Deposits}

Individual pegmatites have various forms including tabular dikes, tabular sills, lenticular bodies, and irregular masses. Even the biggest LCT pegmatite bodies are much smaller than typical granitic plutons. One of the largest and richest pegmatites, Greenbushes, is only $3-\mathrm{km}$ long and a few hundred meters across (Partington and others, 1995). Most LCT pegmatites are much smaller than this.

Most LCT pegmatite bodies show some sort of structural control; the specifics are a function of depth of emplacement and vary from district to district. At shallower crustal depths, pegmatites tend to be intruded along anisotropies such as faults, fractures, foliation, and bedding (Brisbin, 1986). In highergrade metamorphic host rocks, pegmatites are typically concordant with the regional foliation, and form lenticular, ellipsoidal, or "turnip-shaped" bodies (Fetherston, 2004).

Most LCT pegmatite bodies are concentrically, but irregularly, zoned (fig. 2). Zoning is both mineralogical and textural. Generalizing from detailed, deposit-scale mapping of hundreds of U.S. pegmatites, Cameron and others (1949) identified four main zones: the border, wall, intermediate, and core zones; the following is a synopsis from that study. (1) The outermost, or border zone, is a chilled margin just inside the sharp intrusive contact between pegmatite and country rock. Typically, the border zone is a few centimeters thick, fine-grained, and composed of quartz, muscovite, and albite. (2) The 
wall zone is typically less than about 3-m thick. The largest crystals seldom exceed about $30 \mathrm{~cm}$, and in general, the grain size is somewhere between that of the fine-grained border and that of the intermediate zone(s), where the largest crystals are to be found. The essential minerals are albite, perthite, quartz, and muscovite. Graphic intergrowths of perthite and quartz are common. Wall zones are mined for muscovite. Tourmaline and beryl may be present. (3) The intermediate zone or zones comprise everything between the wall and the core. These may be discontinuous rather than complete shells, there may be more than one, or there may be none at all. The essential minerals are plagioclase and potassium feldspars, micas, and quartz. In more evolved LCT pegmatites, various rare-element phases such as beryl, spodumene, elbaite, columbite-tantalite, pollucite, and lithium phosphates are present. Overall grain-size is coarser than in the wall zone. (4) The core zone in many zoned pegmatites is monomineralic quartz. In some core zones, quartz is joined by perthite, albite, spodumene or other lithium aluminosilicates, and (or) montebrasite (London, 2008).

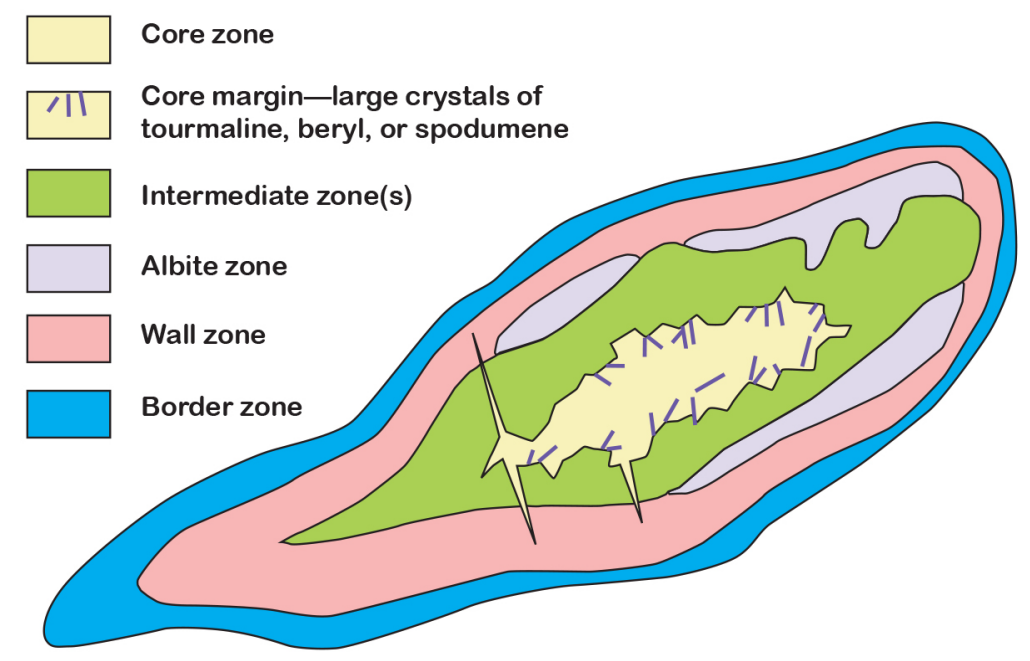

Figure 2. Deposit-scale zoning patterns in an idealized pegmatite, redrafted from Fetherston (2004) and Ĉerný (1991).

The diversity of valid mineral species in the most evolved LCT pegmatites is impressive; at Tanco, for example, 105 minerals have been identified (London, 2008). Huge crystals are another hallmark of LCT pegmatites. The biggest spodumene was 14-m long; the biggest beryl, $18 \mathrm{~m}$; and the biggest potassium feldspar, $49 \mathrm{~m}$ (Rickwood, 1982). These are all the more remarkable because pegmatites are believed to have crystallized in a matter of days to years (London, 2008).

\section{Geologic Assessment Guidelines}

In areas of good bedrock exposure, LCT pegmatites are readily recognized: they are lightcolored rocks with enormous crystals. The pegmatites of the White Picacho district in Arizona, for example, are plainly seen in Google Earth images. Granitic pegmatites are relatively resistant and tend to stand above their surroundings. This is the case in heavily wooded western Maine, where many of the glacially sculpted hilltops are pegmatites. The quartz cores of pegmatites are particularly resistant, and in some climates (for example, Tabba Tabba in Australia) (Sweetapple and Collins, 2002), the quartz core may be all that is exposed. 
The identification of possible granitic parents is a key step in evaluating a region for LCT pegmatite potential. Fertile, peraluminous granites typically contain coarse muscovite that is green rather than silvery; potassium feldspar that is white rather than pink; and accessory garnet, tourmaline, fluorite, and (or) cordierite (Selway and others, 2005). Fertile granites have high cesium, lithium, rubidium, tin, and tantalum, and low calcium, iron and magnesium; they also have unusual elemental ratios (for example, $\mathrm{Mg} / \mathrm{Li}<10$ and $\mathrm{Nb} / \mathrm{Ta}<8$ ) (Selway and others, 2005). Because not all LCT pegmatites can be linked to a known parental granite, the absence of fertile granites at the surface does not rule out the potential for LCT pegmatites.

Exploration guidelines that make use of mineralogical and geochemical zonation have been summarized by Selway and others (2005). LCT pegmatites typically occur in groups, which consist of tens to hundreds of individuals and cover areas up to a few tens of square kilometers (Ĉerný, 1991). LCT pegmatites are known to form as far as $10 \mathrm{~km}$ from the parental granite (Breaks and Tindle, 1997), the distal ones being most fractionated. The pegmatites in a group typically show mineralogical and geochemical zonation that is concentric about an exposed or inferred granitic pluton-both in map view and in cross-section. The most proximal and least evolved pegmatite bodies in an LCT field contain only the standard rock-forming minerals of an S-type granite. In the most fractionated pegmatites in successive regional zones, beryl appears, then columbite, then tantalite and spodumene, and finally pollucite. The most highly fractionated rare-element-enriched pegmatites only constitute 1 or 2 percent of regional pegmatite populations (Ginsburg and others, 1979; Stewart, 1978).

Within a frontier pegmatite district, a number of mineral fractionation trends may help to reveal regional zonation and thus point toward the most promising ground. Potassium feldspars from the most fractionated pegmatites contain $>3000 \mathrm{ppm} \mathrm{Rb}, \mathrm{K} / \mathrm{Rb}<30$, and $>100 \mathrm{ppm}$ Cs (Selway and others, 2005). Similarly, muscovites from the most fractionated pegmatites contain $>2000 \mathrm{ppm} \mathrm{Li},>10,000$ ppm Rb, and >500 ppm Cs (Selway and others, 2005). Smeds (1992) observed that in Swedish pegmatites, $\mathrm{Sn}>500 \mathrm{ppm}$ in muscovite is a good indicator of cassiterite, especially when coupled with low magnesium and iron. Garnets change both in color and composition with increasing fractionation (Selway and others, 2005). Fertile granites contain red, iron-rich almandine whereas the most evolved pegmatites may contain orange, manganese-rich spessartine. Tourmaline in fertile granites and the outer zones of LCT pegmatites is black and low in lithium and manganese; the inner zones of the most fractionated pegmatites commonly bear tourmaline in the pink to green variety elbaite, which is high in lithium and manganese. Beryl shows color changes with increasing fractionation, from greenish or brownish in less evolved pegmatites, to pale, white, and pink in more evolved bodies (Trueman and Ĉerný, 1982).

Weathering of LCT pegmatites can result in both soil anomalies and indicator minerals. Smith and others (1987) demonstrated that arsenic, beryllium, antimony, and tin form a 12- by 20-km halo in lateritic soils around the Greenbushes pegmatite; niobium, tantalum, and boron form a smaller, 1- by 5$\mathrm{km}$ halo. Cassiterite, tantalite, elbaite, and spessartine are sufficiently dense and durable to serve as heavy indicator minerals.

Highly mobile elements such as lithium, rubidium, and cesium, and volatile components like boron and fluorine tend to alter the adjacent country rocks during LCT pegmatite emplacement. For example, a large alteration halo of lithium and a smaller one of rubidium directly overlie the buried Tanco pegmatite (Trueman and Ĉerný, 1992). In mafic rocks, the purple, lithium-bearing amphibole holmquistite may form in haloes up to $20 \mathrm{~m}$ beyond the responsible pegmatite (London, 1986). 


\section{References Cited}

Bradley, D.C., 2011, Secular trends in the geologic record and the supercontinent cycle: Earth-Science Reviews, v. 108, p. 16-33.

Breaks, F.W., and Moore, J.M., 1992, The Ghost Lake Batholith, Superior Province of Northwestern Ontario: A fertile, S-type, peraluminous granite-Rare element pegmatite system: Canadian Mineralogist, v. 30, p. 835-875.

Breaks, F.W. and Tindle, A.G., 1997, Rare-element exploration potential of the Separation Lake area: an emerging target for Bikita-type mineralization in the Superior Province of Ontario: Ontario Geological Survey, Open File Report 5966, 27 p.

Brisbin, W.C., 1986, Mechanics of pegmatite intrusion: American Mineralogist, v. 71, p. 644-651.

Cameron, E.N., Jahns, R.H., McNair, A.H., and Page, L.R., 1949, Internal structure of granitic pegmatites: Economic Geology Monograph 2, 115 p.

Ĉerný, Petr, 1991, Rare-element granitic pegmatites, part II-Regional to global environments and petrogenesis: Geoscience Canada, v. 18, no. 2, p. 68-81.

Cerný, Petr, 1992, Geochemical and petrogenetic features of mineralization in rare-element granitic pegmatites in the light of current research: Applied Geochemistry, v. 7, no. 5, p. 393-416.

Ĉerný, Petr, Masau, M., Goad, B.E., and Ferreira, K., 2005, The Greer Lake leucogranite, Manitoba, and the origin of lepidolite-subtype granitic pegmatites: Lithos, v. 80, nos. 1-4, p. 305-321.

Fetherston, J.M., 2004, Tantalum in Western Australia: Western Australia Geological Survey, Mineral Resources Bulletin 22, $162 \mathrm{p}$.

Ginsburg, A.I., Timofeyev, L.N., and Feldman, L.G., 1979, Principles of Geology of the Granitic Pegmatites: Nedra, Moscow, 296 p. [In Russian].

Kontak, D.J., 2006, Nature and origin of an LCT-suite pegmatite with late-stage sodium enrichment, Brazil Lake, Yarmouth county, Nova Scotia. I. Geological setting and petrology: Canadian Mineralogist v. 44, p. 563-598.

London, David, 1986, Holmquistite as a guide to pegmatitic rare metal deposits: Economic Geology, v. 81, p. 704-712.

London, David, 2008, Pegmatites: The Canadian Mineralogist Special Publication 10, 347 p.

Martin, R.F., and De Vito, C., 2005, The patterns of enrichment in felsic pegmatites ultimately depend on tectonic setting: Canadian Mineralogist v. 43, p. 2027-2048.

McCauley, A., and Bradley, D., 2011, Age distribution of lithium-cesium-tantalum enriched pegmatites and relationships to orogeny: AGU Fall Meeting 2011, abstract V13B-2600.

Partington, G.A., McNaughton, N.J., and Williams, I.S., 1995, A review of the geology, mineralization and geochronology of the Greenbushes pegmatite, Western Australia: Economic Geology, v. 90, p. 616-635.

Rickwood, P.C., 1982, The largest crystals: American Mineralogist, v. 66, p. 885-907.

Selway, J.B., Breaks, F.W., and Tindle, A.G., 2005, A review of rare-element (Li-Cs-Ta) pegmatite exploration techniques for the Superior Province, Canada, and large worldwide tantalum deposits: Exploration and Mining Geology, v. 14, nos. 1-4, p. 1-30.

Smeds, S.A., 1992, Trace elements in potassium-feldspar and muscovite as a guide in the prospecting for lithium- and tin-bearing pegmatites in Sweden: Journal of Geochemical Exploration, v. 42, p. 351-369.

Smith, R.E., Perdrix, J.L., and Davis, J.M., 1987, Dispersion into pisolitic laterite from the Greenbushes mineralized Sn-Ta pegmatite system, Western Australia: Journal of Geochemical Exploration, v. 28, p. 251-265.

Stewart, D.B., 1978, Petrogenesis of lithium-rich pegmatites: American Mineralogist, v. 63, p. 970-980. 
Sweetapple, M.T., and Collins, P.L.F., 2002, Genetic framework for the classification and distribution of Archean rare metal pegmatites in the north Pilbara Craton, Western Australia: Economic Geology, v. 97, p. $873-895$.

Symons, D.T.A., Smith, T.E., Kawasaki, K., and Walawender, M.J., 2009, Paleomagnetism of the midCretaceous gem bearing pegmatite dikes of San Diego County, California, USA: Canadian Journal of Earth Science, v. 46, p. 675-687.

Tkachev, A.V., 2011, Evolution of metallogeny of granitic pegmatites associated with orogens throughout geological time: Geological Society, London, Special Publication 350, p. 7-23.

Trueman, D.L., and Ĉerný, Petr, 1982, Exploration for rare-element granitic pegmatites: Mineralogical Association of Canada, Short Course Handbook 8, p. 463-493.

U.S. Geological Survey, 2011, Mineral commodity summaries 2011: U.S. Geological Survey, 198 p. 